Promotion Effect of Sulfite on Deoxyosones and 4-Methylimidazole in Caramel

\title{
Model System
}

$$
\text { Xian-Bing } \mathrm{Xu}^{1, \#} \text { Pei } \mathrm{Yu}^{2, \#} \text { Shu-Juan } \mathrm{Yu}^{2,3^{*}}
$$

1National Engineering Research Center of Seafood, School of Food Science and

Technology, Dalian Polytechnic University, Dalian 116034, China

2 College of Light Industry and Food Sciences, South China University of

Technology, Guangzhou 510640, China

3 Guangdong Province Key Laboratory for Green Processing of Natural Products and Product Safety, Guangzhou 510640, China

\footnotetext{
\# These authors contributed equally to this work and should be considered co-first authors

*Corresponding author: Shu-Juan Yu; e-mail: shujuanyu8@ gmail.com; Tel.: +86 20 87113668, Fax: +86 2087113668
} 
1 Abstract: In this study, hydrogen-deuterium (H/D) exchange experiment was carried

2 out to reveal the promotion effect of sulfite on the formation of deoxyosones and

3 4-methylimidazole (4-MeI) in the Maillard reaction. Glucose-ammonium (40 mmol/L,

4 pH 7.4 in PBS) model systems with different levels of sulfite were incubated at

$5 \quad 110{ }^{\circ} \mathrm{C}$ for $2 \mathrm{~h}$. Alpha-dicarbonyls were detected after derivatization by a

6 high-performance liquid chromatography with a diode array detector (HPLC-DAD).

$7 \quad$ 4-MeI in the Maillard reaction was tested using a high-performance anion exchange

8 chromatography with an electrochemical detector (HPAEC-ED). The H/D exchange

9 ratios of hexose (fructose, glucose and mannose) were tested by HPAEC-MS. Results

10 showed that the aldo-enol transition of enediol was promoted by sulfite, which

11 promoted the formation of deoxyosones and 4-MeI. In addition, the oxidation reaction

12 of enediols was inhibited by the antioxidant sulfite, which caused the inhibition of

13 osones formation in the Maillard reaction.

14 Keyword: 4-methylimidazole, alpha-dicarbonyls, sulfite, enediol, Class IV caramel 15 color, $\mathrm{H} / \mathrm{D}$ exchange 


\section{Introduction}

Caramel color is widely applied for coloring a variety of foods and beverages (Chappel \& Howell, 1992). Four classes of caramel color (classes I, II, III, and IV) are divided on the basis of the application and the reactants used in the caramel color manufacture (Hengel \& Shibamoto, 2013). Typically, class IV compounds, widely used in soft drinks, are produced thermally by carbohydrates with both sulfite-containing and ammonium-containing compounds. However, many studies on the toxicity of caramel color reported that class IV caramel color contained carcinogenic compounds such as 4-methylimidazole (4-MeI) (Brusick, Jagannath, Galloway, \& Nestmann, 1992; Moon \& Shibamoto, 2010). Thus, a great deal of attention was attracted among US and European food safety agencies (Lee, Jang, \& Shibamoto, 2012).

Except for the addition into the manufacture of caramel color, sulfite is the most widespread anti-brown agent which inhibits the formation of the brown polymer in the final Maillard reaction stage (Y.-G. Guan, Zhu, Yu, Xu, \& Zhu, 2013; Iyengar \& McEvily, 1992). Meanwhile, the addition of sulfite in the Maillard reaction is also used to control harmful compounds formation, including 4-MeI (Jang, Jiang, Hengel, \& Shibamoto, 2013), 5-hydroxymethyl-2-furaldehyde (Y. G. Guan, Zhu, Yu, Xu, \& Shi, 2011) and N-epsilon-(carboxymethyl)-lysine (X.-B. Xu, Ma, Yu, \& Guan, 2013). Jang et al. (Jang, Jiang, Hengel, \& Shibamoto, 2013) also reported that adding sulfite was effective on inhibiting dicarbonyls formation such as methylglyoxal (MGO). Noted that sulfite based on the reports mentioned above always shows inhibitory 
behavior in control of the Maillard reaction due to the nucleophilic property of sulfite, which is facile to adduct with carbonyl group from carbohydrates, Amadori rearrangement products (ARPs) or dicarbonyls and subsequently blocks the further reaction of carbonyls to form the relevant compounds. Recently, Lee et al. (Lee, Jang, \& Shibamoto, 2012) reported the promotion effect of sulfite on 4-MeI formation, but the detailed explanation was not proposed. Therefore, a profound mechanism research should be carried out to comprehensively understand the role of sulfite in the Maillard reaction.

MGO, a proposed precursor compound of 4-MeI, has been detailed on its formation via carbohydrate degradation undergoing caramelization and the Maillard reaction (Weigel, Opitz, \& Henle, 2004). The origin of MGO from reported views has included sugars, ARPs and long-chain dicarbonyls (such as 3-deoxyglucosone (3-DG) and 1-deoxyglucosone) regardless of Schiff base (Davidek, Clety, Aubin, \& Blank, 2002; Gobert \& Glomb, 2009; Usui, Yanagisawa, Ohguchi, Yoshino, Kawabata, Kishimoto, et al., 2007). Subsequently, Gobert et al. (Gobert \& Glomb, 2009) summarized that three major pathways leading to the formation of MGO were retro-aldol reactions, $\alpha$ - and $\beta$-dicarbonyl cleavages. In addition, during heating and storage, MGO formed from the Maillard reaction is recognized as an important precursor of 4-MeI (Moon \& Shibamoto, 2010). Thus, it is important to control the formation of MGO in the Maillard reaction.

In this study, the H/D exchange experiment was carried out to investigate the mechanism of sulfite on the promotion of 4-MeI and deoxyosones in the Maillard 
reaction. In addition, the precursor compounds, such as glucosone, 3-DG and MGO, were also monitored for proposing the appropriate mechanism for effect of sulfite on the 4-MeI formation.

\section{Materials and Methods}

\subsection{Chemicals}

Methanol was chromatographic grade and purchased from Merck (Damstadt, Germany). $\quad \mathrm{D}_{2} \mathrm{O}$ (99\%), D-glucose (Glc, 99\%), arabinose (99\%), ammonium hydroxide solution (25\%), o-phenylenediamine (OPD, 99\%), sodium sulfite (98\%), disodium hydrogen phosphate dodecahydrate (98\%) and sodium dihydrogen phosphate dehydrate (98\%) were purchased from Sigma-Aldrich (St. Louis, MO, USA). Sodium hydroxide (50\%) used for HPAEC analysis was chromatographic grade and obtained from Sigma-Aldrich (St. Louis, MO, USA).

\subsection{Preparation of class III and IV caramel color}

Different levels of sodium sulfite (the final concentration of sulfite: $0,20,40,100$ or $400 \mathrm{mmol} / \mathrm{L})$ were spiked into the solution of Glc-NH4 $4^{+}(40 \mathrm{mmol} / \mathrm{L}, 1: 1)$ in PBS $(0.2$ $\mathrm{mol} / \mathrm{L}, \mathrm{pH}$ 7.4). Four milliliter mixtures were incubated at $110{ }^{\circ} \mathrm{C}$ for up to $120 \mathrm{~min}$ in a swing-top bottle. After a defined reaction time, the reaction mixtures were cooled to room temperature by iced water immediately to stop the reaction. One milliliter reaction mixture was incubated using OPD $(1 \mathrm{~mL}, 0.5 \mathrm{mg} / \mathrm{mL}$ in $0.2 \mathrm{~mol} / \mathrm{L}$ PBS of $\mathrm{pH}$ 7.4) for $12 \mathrm{~h}$ at room temperature and the rest of reaction mixture was stored at $4^{\circ} \mathrm{C}$ for further analyses.

\subsection{H/D exchange samples in the Maillard reaction}


According to Biemel et al. (Biemel, Conrad, \& Lederer, 2002), $\mathrm{D}_{2} \mathrm{O}$ was used as the deuterium source of the Maillard reaction, $\mathrm{Glc}^{-\mathrm{NH}_{4}}{ }^{+}(40 \mathrm{mmol} / \mathrm{L}, 1: 1)$ in phosphate buffer deuteroxide solutions $(0.2 \mathrm{~mol} / \mathrm{L}, \mathrm{pH} 7.4)$ was reacted at $110{ }^{\circ} \mathrm{C}$ for up to 120 min after adding different levels of sulfite sodium (the final concentration of sulfite: 0 , 20 and $40 \mathrm{mmol} / \mathrm{L}$, respectively.). After a defined reaction time, the reaction mixtures were cooled to room temperature by iced water immediately to stop the reaction.

\subsection{Syntheses of Quinoxalines}

Quinoxalines were prepared according to the method of Morita et al. (1983) with a slight modification (Morita, Mizutani, Hayashi, Kirihata, Ichimoto, Ueda, et al., 1983). Glucose or arabinose was mixed with OPD and stirred for $4 \mathrm{~h}$ at $60{ }^{\circ} \mathrm{C}$ in $20 \mathrm{~mL}$ aqueous solution. The crude products were purified by a $\mathrm{C}_{18}(10 \mu \mathrm{m})$ column $(30 \times$ $200 \mathrm{~mm}$, inside diameter $\times$ length, lisui II) with a ultraviolet detector (Lisui, Suzhou Lisui Technology Co., Ltd, China) by elution with methanol /water $(2: 8, \mathrm{v} / \mathrm{v})$ at a flow rate of $18 \mathrm{ml} / \mathrm{L}$. The isolated quinoxalines was collected and dried in vacuum. The solvent was eliminated by vacuum concentration, and then freeze-dried (white powder, $60 \mathrm{mg}) .{ }^{1}$ H NMR spectra was recorded on a Bruker AVANCE AV 400 spectrometer with DMSO as solvent at $400 \mathrm{MHz}$ at $30^{\circ} \mathrm{C}$. HRMS was worked on a Bruker maXis impact mass spectrometer instrument.

Glucosone-Quinoxaline ( $\mathrm{Q}, \mathrm{t}_{\mathrm{R}}$ 15-17 $\mathrm{min}$ ). HR-MS: m/z 273.0852 (found); m/z 273.0846 (calculated for $\left.\mathrm{C}_{12} \mathrm{H}_{14} \mathrm{~N}_{2} \mathrm{O}_{4} \mathrm{Na}\right) \quad[\mathrm{M}+\mathrm{Na}]^{+} .{ }^{1} \mathrm{H}$ NMR (400 MHz, in DMSO-d6): $\delta / p p m=3.34(\mathrm{~s}, 4 \mathrm{H}), 3.66(\mathrm{dd}, \mathrm{J}=4 \mathrm{~Hz}, 1 \mathrm{H}), 4.65(\mathrm{~m}, 1 \mathrm{H}), 5.14$ (d, J=2 Hz, 1H), 5.59 (d, J=1.2 Hz, 1H), 7.80 (m, 2H), 8.05 (m, 2H), 9.08 (s, 1H). 
Pentosone-Q ( $\mathrm{t}_{\mathrm{R}}$ 16.5-17.3 $\mathrm{min}$ ). HR-MS: verified $\mathrm{m} / \mathrm{z} 243.0743$ (found); $\mathrm{m} / \mathrm{z}$ 243.0740 (calculated for $\left.\mathrm{C}_{11} \mathrm{H}_{12} \mathrm{~N}_{2} \mathrm{O}_{3} \mathrm{Na}\right) \quad[\mathrm{M}+\mathrm{Na}]^{+} .{ }^{1} \mathrm{H}$ NMR (400 $\mathrm{MHz}$, in DMSO-d6): $\delta / \mathrm{ppm}=3.47(\mathrm{~m}, 1 \mathrm{H}), 3.61(\mathrm{~m}, 1 \mathrm{H}), 3.90(\mathrm{~m}, 1 \mathrm{H}), 4.78(\mathrm{~d}, \mathrm{~J}=4 \mathrm{~Hz}, 1 \mathrm{H})$, 7.76-7.84 (m, 2H), 8.01-8.07 (m, 2H), $9.05(\mathrm{~s}, 1 \mathrm{H})$.

Threosone-Q ( $\mathrm{t}_{\mathrm{R}}$ 17.5-18.5 $\mathrm{min}$ ). HR-MS: verified $\mathrm{m} / \mathrm{z} 213.0635$ (found); $\mathrm{m} / \mathrm{z}$ 213.0634 (calculated for $\mathrm{C}_{10} \mathrm{H}_{10} \mathrm{~N}_{2} \mathrm{O}_{2} \mathrm{Na}$ ) $[\mathrm{M}+\mathrm{Na}]^{+}$. NMR results were in line with Usui et al. (Usui, et al., 2007).

3-Deoxyglucosone-Q (3-DG-Q, $\mathrm{t}_{\mathrm{R}}$ 18-20 min). HR-MS: m/z 257.0896 (found); m/z 257.0897 (calculated for $\left.\mathrm{C}_{12} \mathrm{H}_{14} \mathrm{~N}_{2} \mathrm{O}_{3} \mathrm{Na}\right)[\mathrm{M}+\mathrm{Na}]^{+}$. ${ }^{1} \mathrm{H} \mathrm{NMR}\left(400 \mathrm{MHz}\right.$, in $\left.\mathrm{CDCl}_{3}\right)$ : $\delta / \mathrm{ppm}=3.14\left(\mathrm{q},{ }^{2} \mathrm{~J}=14.1 \mathrm{~Hz},{ }^{3} \mathrm{~J}=9.7 \mathrm{~Hz}, 1 \mathrm{H}\right), 3.43\left(\mathrm{q},{ }^{2} \mathrm{~J}=14.0 \mathrm{~Hz},{ }^{3} \mathrm{~J}=2.8 \mathrm{~Hz}, 1 \mathrm{H}\right)$, $3.61(\mathrm{~m}, 1 \mathrm{H}), 3.65\left(\mathrm{q},{ }^{2} \mathrm{~J}=11.4 \mathrm{~Hz},{ }^{3} \mathrm{~J}=5.7 \mathrm{~Hz}, 1 \mathrm{H}\right), 3.80\left(\mathrm{q},{ }^{2} \mathrm{~J}=11.0 \mathrm{~Hz},{ }^{3} \mathrm{~J}=3.7 \mathrm{~Hz}\right.$, 1H), $4.09(\mathrm{~m}, 1 \mathrm{H}), 7.80(\mathrm{~m}, 2 \mathrm{H}), 8.05(\mathrm{~m}, 2 \mathrm{H}), 8.85(\mathrm{~s}, 1 \mathrm{H})$.

Hydroxypyruvaldehyde-Q (HPA-Q, $\left.\mathrm{t}_{\mathrm{R}} \quad 20-23 \mathrm{~min}\right) .{ }^{1} \mathrm{H}$ NMR (400 $\mathrm{MHz}$, in DMSO-d6): $\delta / \mathrm{ppm}=4.83\left[\mathrm{~s}, 2 \mathrm{H},-\mathrm{CH}_{2}(\mathrm{OH})\right], 7.76-7.84(\mathrm{~m}, 2 \mathrm{H}), 8.01-8.07(\mathrm{~m}, 2 \mathrm{H})$, 9.05 (s, 1H, N=CH-); HR-MS: m/z 161.0709 (found); m/z 161.0712 (calculated for $\left.\mathrm{C}_{9} \mathrm{H}_{9} \mathrm{~N}_{2} \mathrm{O}\right)[\mathrm{M}+\mathrm{H}]^{+}$.

MGO-Q was verified in comparison to commercial available materials.

\subsection{Analyses of dicarbonyls by HPLC-UV}

Identification of alpha-dicarbonyls as quinoxalines was carried out according to Gobert and Glomb (Gobert \& Glomb, 2009) with slight modifications. The analyses were performed in an HPLC-DAD system, which consisted of a $5 \mu \mathrm{m}$ Waters Atlantis T3 $150 \times 4.6 \mathrm{~mm}$ column (Waters Co., USA), a Waters 600 pump and a Waters 2998 
diode array detector (Waters Co., USA). $1.0 \mathrm{~mL}$ reaction solution was mixed with 1 $\mathrm{mL}$ OPD solution $(0.5 \mathrm{mg} / \mathrm{mL})$, and reacted at $25^{\circ} \mathrm{C}$ for $12 \mathrm{~h}$ in dark. The injection volume was $20 \mu \mathrm{L}$ (filtered through $0.45 \mu \mathrm{m}$ filters), and the mobile phases were methanol and water, and set as $5 \% \mathrm{v} / \mathrm{v}$ methanol, 0-5 min, then a linear gradient from $5 \% \mathrm{v} / \mathrm{v}$ methanol to $30 \% \mathrm{v} / \mathrm{v}$ methanol, 5-10 min, subsequently, changed to $40 \% \mathrm{v} / \mathrm{v}$ methanol, 10-45 min, at last, $100 \% \mathrm{v} / \mathrm{v}$ methanol was used for elution from 45 to 65 min at a flow rate of $1 \mathrm{~mL} / \mathrm{min}$. Column temperature was set at $25^{\circ} \mathrm{C}$. Spectral data from all peaks were accumulated in the range of $200-600 \mathrm{~nm}$, and chromatograms were recorded at $315 \mathrm{~nm}$.

\subsection{Analyses of 4-MeI by HPAEC-ED}

The analysis of 4-MeI was carried out according to the literature (X. B. Xu, Liu, Yu, Yu, \& Zhao, 2015), Ansys SPEC SCX Disc 15 mg/3 mL cartridge (Varian, Walnut Creek, CA) was conditioned with $1 \mathrm{~mL}$ methanol and $1 \mathrm{~mL}$ water. The $3 \mathrm{~mL}$ Maillard reaction mixtures acidified with $20 \mu \mathrm{L} \mathrm{HCl}(0.1 \mathrm{~mol} / \mathrm{L})$ were loaded and passed through the cartridge. The retained 4-MeI was eluted out with $6 \mathrm{~mL}$ methanol/ammonia $(5 \%, \mathrm{v} / \mathrm{v})$. The collected extract was evaporated by vacuum concentration at $39^{\circ} \mathrm{C}$, and the residues were dissolved by $3 \mathrm{~mL}$ deionized water for HPAEC-ED analyses.

The pretreated samples were filtered through a Millex-HN nylon clarification kit of $0.45 \mu \mathrm{m}$ pore size (Millipore, Bedford, MA), and then analyzed on a DX 5000 Dionex system (Dionex Corp., Sunnyvale, CA), which consisted of a gradient pump (model EG40) with on-line degassing and an electrochemical detector (ED, ED40, Dionex 
Corp., Sunnyvale, CA). Separation was accomplished on an amino trap column $(50 \times 4$ mm, Dionex, P/N: 046122). The mobile phase was isocratic elution with $100 \mathrm{mM}$ $\mathrm{NaOH}$ at a flow rate of $0.5 \mathrm{~mL} / \mathrm{min}$. The injection volume was $20 \mu \mathrm{L}$. The $\mathrm{pH}$ reference electrode and gold electrode were used in HPAEC-ED analyses. The waveforms were applied under the following settings: $E_{1}=0.13 \mathrm{~V}\left(\mathrm{t}_{1}=0.04 \mathrm{~s}\right), \mathrm{E}_{2}=0.33$ $\mathrm{V}\left(\mathrm{t}_{2}=0.16 \mathrm{~s}\right), \mathrm{E}_{3}=0.55 \mathrm{~V}\left(\mathrm{t}_{3}=0.24 \mathrm{~s}\right), \mathrm{E}_{4}=0.33 \mathrm{~V}\left(\mathrm{t}_{4}=0.09 \mathrm{~s}\right), \mathrm{E}_{5}=-1.67 \mathrm{~V}\left(\mathrm{t}_{5}=0.01 \mathrm{~s}\right)$, $\mathrm{E}_{6}=0.93 \mathrm{~V}\left(\mathrm{t}_{6}=0.01 \mathrm{~s}\right), \mathrm{E}_{7}=0.13 \mathrm{~V}\left(\mathrm{t}_{7}=0.01 \mathrm{~s}\right)$. Integration occurred from 0.20 to $0.44 \mathrm{~s}$ during $\mathrm{E}_{3}$ application.

The regression equation for 4-MeI standard was as follows: $\mathrm{y}_{1}=16.480 \mathrm{x}_{1}+0.479$; $\mathrm{R}^{2}=0.9999$, where $\mathrm{x}_{1}$ was 4 -MeI concentration, $\mathrm{mg} / \mathrm{L}$; $\mathrm{y}_{1}$ was the peak area of 4-MeI. The retention time of 4-MeI was about $8.5 \mathrm{~min}$, and the detection range was 0.100 to $10.000 \mathrm{mg} / \mathrm{L}$ in this test, the recovery of the $4-\mathrm{MeI}$ in reaction mixtures was about $96 \%$ $(w / w)$.

\subsection{Glucose and its tautomer analyzed by HPAEC-MS}

According to the literature (X. B. Xu, Liu, Guo, Yu, \& Yu, 2014), H/D exchange ratio of glucose and its tautomers (fructose and mannose) in the Maillard reaction was analyzed by HPAEC-MS. A Dionex ICS 5000 system (Dionex Corp., USA) coupled with a gradient pump (model EG40) with on-line degassing was used for HPAEC. The separation was performed on a CarboPac PA1 $(2 \mathrm{~mm} \times 250 \mathrm{~mm})$ column with a CarboPac PA1 guard $(2 \mathrm{~mm} \times 50 \mathrm{~mm})$ column (Dionex). A flow rate of $0.30 \mathrm{~mL} / \mathrm{min}$ at $30{ }^{\circ} \mathrm{C}$ was used for separations. A two-step gradient was used as follows: $10 \mathrm{mmol} / \mathrm{L}$ $\mathrm{NaOH}(0-25 \mathrm{~min})$ for monosaccharide analysis, and $100 \mathrm{mmol} / \mathrm{L} \mathrm{NaOH}(25-45 \mathrm{~min})$ 
171 for disaccharide analysis. The injection volume was $25 \mu \mathrm{L}$. For conversion of the 172 eluate into an ESI-compatible solution, an ASRS 300 suppressor (2 mm; Dionex, 173 USA) was used as an in-line desalter; it was set at a constant current of $75 \mathrm{~mA}$ and 174 operated in external water mode (regenerant flow rate approximately $3 \mathrm{~mL} / \mathrm{min}$ ). The converted chromatographic effluent was introduced into the ESI-MS for sugar analysis. Xcalibur software was used for auto-control of the entire system and data 177 acquisition.

178 The ESI-MS operating conditions were as follows: electrospray voltage $5.0 \mathrm{kV}$, 179 nitrogen sheath gas flow $9 \mathrm{~L} / \mathrm{min}$, and nitrogen auxiliary gas flow $3 \mathrm{~L} / \mathrm{min}$. The temperature of the heated capillary was set at $275{ }^{\circ} \mathrm{C}$. A sheath liquid consisting of 50 $\mathrm{mM} \mathrm{NH} \mathrm{NH}_{4} \mathrm{Ac}$ in isopropanol with $0.05 \%$ acetic acid, infused into ESI source at a flow rate of $3 \mu \mathrm{L} / \mathrm{min}$. The $\mathrm{MS}$ of glucose, fructose and mannose was detected as quasi-molecular ions $\left[\mathrm{M}+\mathrm{NH}_{4}\right]^{+}$in positive-ion mode, the value of mass-to-charge ratio $(\mathrm{m} / \mathrm{z})$ was 198 , the deuterated (d) sugars in the Maillard reaction contained hexose-d and hexose-d2, m/z value of which was 199 and 200, respectively.

The regression equation for glucose standard was as follows: $\mathrm{y}_{2}=52.263 \mathrm{x}_{2}-821.6$; $\mathrm{R}^{2}=0.9993$, where $\mathrm{x}_{2}$ was glucose concentration, $\mathrm{mg} / \mathrm{L} ; \mathrm{y}_{2}$ was the peak area of 188 glucose. The regression equation for fructose standard was as follows: $\mathrm{y}_{3}=40.235 \mathrm{x}_{3}-741 ; \mathrm{R}^{2}=0.9869$, where $\mathrm{x}_{3}$ was fructose concentration, $\mathrm{mg} / \mathrm{L} ; \mathrm{y}_{3}$ was the peak area of fructose. The regression equation for mannose standard was as follows: $\mathrm{y}_{4}=65.124 \mathrm{x}_{4}-596 ; \mathrm{R}^{2}=0.9989$, where $\mathrm{x}_{4}$ was mannose concentration, $\mathrm{mg} / \mathrm{L} ; \mathrm{y}_{4}$ was the peak area of mannose. 
$194=\mathrm{M}_{\mathrm{m} / \mathrm{z}}^{\mathrm{a}} /(\mathrm{M}$ [hexose $]+\mathrm{M}[$ hexose- $\mathrm{d}]+\mathrm{M}$ [hexose- $\left.\left.\mathrm{d} 2\right]\right) \times 100$. Where $\mathrm{W}_{\mathrm{m} / \mathrm{z}}^{\mathrm{a}}$ was the 195 percent label distribution of sugar a with the value of $\mathrm{m} / \mathrm{z}, \mathrm{M}_{\mathrm{m} / \mathrm{z}}^{\mathrm{a}}$ was the weight of 196 sugar a with the value of $\mathrm{m} / \mathrm{z}, \mathrm{M}$ [hexose] was the weight of hexose $(\mathrm{m} / \mathrm{z}=198), \mathrm{M}$ 197 [hexose-d] was the weight of hexose-d (m/z=199), M [hexose-d2] was the weight of 198 hexose-d2 $(\mathrm{m} / \mathrm{z}=200)$.

\subsection{Statistical analysis}

Means and standard deviations of the data were calculated for each treatment. Analysis of variance (ANOVA) was carried out to determine any significant differences $(p<0.05)$ among the applied treatments by the SPSS software package (SPSS 10.0 for windows).

\section{Results and discussion}

\subsection{Identification of alpha-dicarbonyl as quinoxalines with HPLC-UV} condition, and all target compounds were eluted out before $30 \mathrm{~min}$.

\subsection{Effect of sulfite on the formation of dicarbonyls}

211 In the present study, the addition of sulfite significantly promoted the formation of 212 deoxyosones (MGO and 3-DG) (Fig. 2A and 2B). After 15 min heating, the formed 213 levels of MGO were up to $0.1,11.2,16.9,28.1$ and $37.1 \mathrm{mmol} / \mathrm{L}$ in the model systems with $0,20,40,100$ or $400 \mathrm{mmol} / \mathrm{L}$ of sulfite addition, respectively. Meanwhile, the 
formed levels of 3 -DG were up to $0.63,0.75,1.37,1.78$ and $2.61 \mathrm{mmol} / \mathrm{L}$ in the model systems in the presence of $0,20,40,100$ or $400 \mathrm{mmol} / \mathrm{L}$ of sulfite, respectively. Moreover, as the heating time was increasing, the levels of deoxyosones in all model systems with sulfite were higher than that in the model system without sulfite.

Besides, the addition of sulfite significantly inhibited the formation of osones (HPA, pentosone, threosone and glucosone) in model reaction systems. The changes of osones were shown in Fig. 2C, 2D, 2E and 2F. HPA and threosone were two major osones in model system without sulfite. After 15 min heating, the contents of HPA and glucosone in model systems without sulfite were increased to the highest concentration (i.e. 7.1 and $0.79 \mathrm{mmol} / \mathrm{L}$, respectively) and then decreased along with the increase of heating time. And the highest contents of pentosone and threosone (i.e. 0.31 and $2.4 \mathrm{mmol} / \mathrm{L}$, respectively) were tested after $30 \mathrm{~min}$ heating. In addition, the levels of osones in all model systems with sulfite were lower than that in the model system without sulfite and the contents of all the four osones were decreased with the increasing sulfite levels, even nearly no HPA, pentosone, threosone and glucosone were detected in the $90 \mathrm{~min}$ reaction after adding $400 \mathrm{mmol} / \mathrm{L}$ sulfite.

Sulfite as a nucleophile generally attacked the carbon atom of the carbonyls to form the hydroxysulphonate. Wedzicha et al. (Wedzicha, Lamikanra, Herrera, \& Panahi, 1984) proposed that sulfite ion could reacted with dicarbonyls (such as 3-DG, 3,4-dideoxyhexosulos-3-ene) to form less reactive products like 3,4-dideoxy-4-sulphohexosulose, which blocked the formation of color. Therefore, sulfite was generally applied to inhibit the non-enzymic browning (Wedzicha \& 
Kaban, 1986). In addition, Jang et al. (Jang, Jiang, Hengel, \& Shibamoto, 2013) proposed that sulfite formed adducts with aldehyde which contributed to the inhibition of 4-MeI formation. Thus, it was concluded that the level of carbonyls in the Maillard reaction would be reduced after sulfite addition due to the formation of adducts of carbonyls with sulfite. In this study, the decrease of osones (such as glucosone, pentosone, HPA and so on) after the addition of sulfite could be explained according to these previous reports. However, the proposed mechanism cannot totally explain the change of deoxyosones (such as 3-DG and MGO) as the addition of sulfite significantly promoted the formation of MGO and 3-DG (Fig. 2A and 2B). The result excluded the fact that the formation of sulfite-aldehyde adducts caused the reduction of dicarbonyls. Therefore, further experiments were required to study the promotion mechanism of sulfite on deoxyosones formation.

\subsection{H/D exchange and tautomerization of glucose in the Maillard reaction}

Further insights to the precise enolization pathway from glucose in the Maillard reaction were achieved by $\mathrm{H} / \mathrm{D}$ exchange experiment. Based on the report in recent literatures, osones were originated from enediol via oxidative reaction (Gobert \& Glomb, 2009; Voigt, Smuda, Pfahler, \& Glomb, 2010). For example, glucosone was produced by glucose oxidation degradation (Usui, et al., 2007). Pentosone, the direct oxidation product of enediol intermediate was detected in aerated glucosone incubations by Gobert and Glomb (Gobert \& Glomb, 2009). In addition, threosone was preferentially formed under aerated conditions in incubation with glucose (Usui, et al., 2007). HPA was formed by the oxidation of glyceraldehyde, which was 
generated from glucose, 3-DG or glucosone via the retro-aldol reaction (Usui, et al., 2007). Therefore, the inhibition of osones formation in this study suggested that the suppression of oxidation of enediol in the Maillard reaction system or decrease of enediol levels was caused by sulfite. In H/D exchange experiment, the total percent distribution of deuterated hexoses was increased from $77.3 \%$ ( $0 \mathrm{mmol} / \mathrm{L}$ sulfite $)$ to $100 \%$ (40 mmol/L sulfite) after sulfite addition (Table 1.). The result indicated that sulfite promoted the eneolization of glucose, which caused the increase of enediols suppression of oxidation of enediol. Moreover, the antioxidation of sulfite had been reported in the literature. Lancia et al.(Lancia, Musmarra, Pepe, \& Prisciandaro, 1997) indicated that the dissolved oxygen in solution could be absorbed via sulfite oxidation.

During the oxidation process, sulfite ion was converted into sulfate ion. Based on the mechanism of sulfite oxidation, sulfite ion in the Maillard reaction system had an ability to exhaust dissolved oxygen in solution and subsequently inhibited the 273 oxidation of enediol to form osones. were absent. In addition, 3-DG was confirmed as the precursor of MGO in recent 

formation of MGO was mainly degraded from 3-DG via the retroaldolisation, which

283 was further confirmed by Yaylayan and Keyhani (Yaylayan \& Keyhani, 2000).

284 Besides, the formation of 3-DG under non-oxidative condition was also confirmed by

285 Usui et al.(Usui, et al., 2007). Therefore, the oxidation pathway was not required for 286 the formation of deoxyosones. 1,2-enediol in the Maillard reaction was achieved from the percent distribution of deuterium tautomerism sugar in H/D experiment. The detailed mechanism of H/D exchange was shown in Fig. 4. When glucose- $\mathrm{NH}_{4}{ }^{+}$system did not contain sulfite, the 291 percent distribution of deuterated hexose was listed in table 1 . Glucose of $21.4 \%$ $(\mathrm{m} / \mathrm{z}=198)$, fructose- $\mathrm{d}$ of $24.4 \%(\mathrm{~m} / \mathrm{z}=199)$ and fructose- $\mathrm{d} 2$ of $24.6 \%(\mathrm{~m} / \mathrm{z}=200)$ were mainly detected in model reaction system, whereas the deuterated/undeuterated mannose and deuterated glucose were tested at a relatively low proportion. Therefore, 295 when sulfite was not added into model reaction system, the isomerization of D-glucose into D-fructose was primarily observed. According to the Lobry de 297 Bruyn-Alberda van Ekenstein transformation (De Wit, Kieboom, \& van Bekkum, 298 1979), glucose (1) was firstly transformed into transition state anion compound 12, 299 when the deuterium ion attacked the oxygen atom at the $\mathrm{C} 1$ or $\mathrm{C} 2$ hydroxyl group 300 with the same chance, the compound 12 was equally transformed via 1,2-eneolization 301 into enediol 3 or 11, keto-enol transition of which was converted into deuterated 302 fructose, including fructose-d $(24.4 \%, \mathrm{~m} / \mathrm{z}=199)$ and fructose- $\mathrm{d} 2(24.6 \%, \mathrm{~m} / \mathrm{z}=200)$. 
However, when sulfite (40 $\mathrm{mmol} / \mathrm{L}$ etc.) was spiked into the model reaction system, the proportion of deuterated fructose was significantly decreased $(4.8 \%$ for fructose-d, $12.8 \%$ fructose-d2), whereas the proportion of deuterated glucose was increased from $13.0 \%$ to $30.7 \%$ (glucose-d), and from $4.1 \%$ to $14.4 \%$ (glucose-d2), and the proportion of deuterated mannose was increased from $8.9 \%$ to $27.1 \%$ (mannose-d), and from $2.3 \%$ to $10.3 \%$ (mannose $-\mathrm{d} 2$ ). The result indicated that sulfite promoted the aldo-enol transformation of enediol compound 3 into glucose and mannose rather than the keto-enol transformation into fructose. Because the steric hindrance contributed to sulfite attacking the proton of hydroxyl at $\mathrm{C} 1$ position rather than $\mathrm{C} 2$ position, aldo-enol transition of enediol compound 3 was the dominant reaction rather than keto-enol transition of enediol compound 3. It was reported that the retro-enolization via aldo-enol transition was the trigger of beta-C3-elimination reaction of 1,2-enediol leading to 3-DG formation (Anet, 1960). Therefore, the promotion of aldo-enol transition by sulfite accelerated the $\mathrm{C} 3$-elimination reaction of 1,2-enediol to form 3-DG, which was subsequently degraded into the increased MGO.

\subsection{Effect of sulfite on 4-MeI formation}

Fig. 3 showed the changes of 4-MeI formation in the Maillard reaction with and without sulfite. Obviously, when sulfite was added into the Maillard reaction system, a higher concentration of 4-MeI was detected comparing with no sulfite addition. After 15, 30, 60, 90 and 120 min reaction, the levels of 4-MeI ranged from 0.61 to $1.42 \mathrm{mg} / \mathrm{L}$ with $100 \mathrm{mmol} / \mathrm{L}$ sulfite addition, comparing with $0.07-0.18 \mathrm{mg} / \mathrm{L}$ in the reaction system without sulfite addition. When the concentration of sulfite increased 
to $200 \mathrm{mmol} / \mathrm{L}$, the $4-\mathrm{MeI}$ levels were reduced, but still higher than that in the model reaction system without sulfite.

Some authors had indicated that MGO was the precursor of 4-MeI formation (Hengel \& Shibamoto, 2013). As a matter of course, the accelerated formation of MGO by sulfite definitely contributed to promoting the formation of 4-MeI. Though the levels of 4-MeI were decreased with high level addition of sulfites $(>200 \mathrm{mmol} / \mathrm{L})$, the amount of 4-MeI was still higher than that in model reaction without sulfite. Therefore, sulfite did not always show inhibitory behavior in control of the Maillard reaction.

\section{Conclusions}

In summary, sulfite promoted the aldo-enol instead of keto-enol transition of enediol transformed from hexose, which caused the increase of deoxyosones and 4-MeI. In addition, the antioxidant sulfite inhibited the oxidation of enediol to generate osones. The results in the present study suggested that sulfite played an important role in the caramel preparations and did not always show inhibitory effect on 4-MeI formation during caramel color IV manufacture.

\section{Acknowledgements.}

All the authors acknowledge financial support from the National Science Foundation of China (Grant No. 31601467), the National Science Foundation of China (GrantNo.31271889), the basic research foundation of SCUT (2014ZP0019), and the Science and Technology Planning Project of Guangdong Province (2013B051000015). 


\section{Reference}

Anet, E. F. L. J. (1960). 3-Deoxyhexosones. Journal Of The American Chemical Society, 82(6), 1502-1502.

Biemel, K. M., Conrad, J., \& Lederer, M. O. (2002). Unexpected Carbonyl Mobility in Aminoketoses: The Key to Major Maillard Crosslinks. Angewandte Chemie International Edition, 41(5), 801-804.

Brusick, D. J., Jagannath, D. R., Galloway, S. M., \& Nestmann, E. R. (1992). Genotoxicity Hazard Assessment of Caramel Colours Iii and Iv. Food And Chemical Toxicology, 30(5), 403-410.

Chappel, C. I., \& Howell, J. C. (1992). Caramel Colours-a Historical Introduction. Food And Chemical Toxicology, 30(5), 351-357.

Davidek, T., Clety, N., Aubin, S., \& Blank, I. (2002). Degradation of the Amadori Compound N-(1-Deoxy-D-Fructos-1-Yl)Glycine in Aqueous Model Systems. Journal Of Agricultural And Food Chemistry, 50(19), 5472-5479.

De Wit, G., Kieboom, A. P. G., \& van Bekkum, H. (1979). Enolisation and Isomerisation of Monosaccharides in Aqueous, Alkaline Solution. Carbohydrate Research, 74(1), 157-175.

Gobert, J., \& Glomb, M. A. (2009). Degradation of Glucose: Reinvestigation of Reactive A-Dicarbonyl Compounds $\uparrow$. Journal of Agricultural and Food Chemistry, 57(18), 8591-8597.

Guan, Y.-G., Zhu, S.-M., Yu, S.-J., Xu, X.-B., \& Zhu, L.-C. (2013). < I> Short Communication: $</ \mathrm{I}>$ Possible Mechanism for Inhibiting the Formation of 

the Dairy Thermal Process. Journal Of Dairy Science, 96(5), 2826-2831.

Guan, Y. G., Zhu, S. M., Yu, S. J., Xu, X. B., \& Shi, W. H. (2011). So $3^{2-}$ Effects the 5- Hydroxymethyl- 2- Furaldehyde Content in Ammonium Sulphite-Glucose Solutions. International Journal of Food Science \& Technology, 46(5), 1007-1013.

Hengel, M., \& Shibamoto, T. (2013). Carcinogenic 4(5)-Methylimidazole Found in Beverages, Sauces, and Caramel Colors: Chemical Properties, Analysis, and Biological Activities. Journal Of Agricultural And Food Chemistry, 61(4), 780-789.

Hollnagel, A., \& Kroh, L. W. (1998). Formation of Alpha-Dicarbonyl Fragments from Mono- and Disaccharides under Caramelization and Maillard Reaction Conditions. Zeitschrift Fur Lebensmittel-Untersuchung Und-Forschung a-Food Research and Technology, 207(1), 50-54.

Iyengar, R., \& McEvily, A. J. (1992). Anti-Browning Agents: Alternatives to the Use of Sulfites in Foods. Trends In Food Science \& Technology, 3(1), 60-64.

Jang, H. W., Jiang, Y., Hengel, M., \& Shibamoto, T. (2013). Formation of 4(5)-Methylimidazole and Its Precursors, A-Dicarbonyl Compounds in Maillard Model Systems. Journal Of Agricultural And Food Chemistry, 61(28), 6865-6872.

Lancia, A., Musmarra, D., Pepe, F., \& Prisciandaro, M. (1997). Model of Oxygen Absorption into Calcium Sulfite Solutions. Chemical Engineering Journal, 66(2), 
Lee, K.-G., Jang, H., \& Shibamoto, T. (2012). Formation of Carcinogenic Chemistry, 136(3), 1165-1168.

Moon, J.-K., \& Shibamoto, T. (2010). Formation of Carcinogenic 4(5)-Methylimidazole in Maillard Reaction Systems. Journal Of Agricultural And Food Chemistry, 59(2), 615-618.

Morita, N., Mizutani, M., Hayashi, K., Kirihata, M., Ichimoto, I., Ueda, H., \& Takagi, M. (1983). Quinoxalines Derived from D-Glucose and Maltose with O-Phenylene-Diamine under Refluxed Conditions in Alkaline Media. Agriculture and Biology, 35, 59-70.

Thornalley, P. J., Langborg, A., \& Minhas, H. S. (1999). Formation of Glyoxal, Methylglyoxal and 3-Deoxyglucosone in the Glycation of Proteins by Glucose. Biochemical Journal, 344(1), 109-116.

Usui, T., Yanagisawa, S., Ohguchi, M., Yoshino, M., Kawabata, R., Kishimoto, J., Arai, Y., Aida, K., Watanabe, H., \& Hayase, F. (2007). Identification and Determination of Alpha-Dicarbonyl Compounds Formed in the Degradation of Sugars. Bioscience Biotechnology And Biochemistry, 71(10), 2465-2472.

Voigt, M., Smuda, M., Pfahler, C., \& Glomb, M. A. (2010). Oxygen-Dependent Fragmentation Reactions During the Degradation of 1-Deoxy-D-Erythro-Hexo-2,3-Diulose. Journal of Agricultural And Food Chemistry, 58(9), 5685-5691. 
Wedzicha, B. L., \& Kaban, J. (1986). Kinetics of the Reaction between 3-Deoxyhexosulose and Sulphur(Iv) Oxospecies in the Presence of Glycine. Food Chemistry, 22(3), 209-223.

Wedzicha, B. L., Lamikanra, O., Herrera, J. C., \& Panahi, S. (1984). Recent Developments in the Understanding of the Chemistry of Sulphur(Iv) Oxospecies in Dehydrated Vegetables. Food Chemistry, 15(2), 141-155.

Weenen, H. (1998). Reactive Intermediates and Carbohydrate Fragmentation in Maillard Chemistry. Food Chemistry, 62(4), 393-401.

Weigel, K., Opitz, T., \& Henle, T. (2004). Studies on the Occurrence and Formation of 1,2-Dicarbonyls in Honey. European Food Research And Technology, 218(2), 147-151.

Xu, X.-B., Ma, F., Yu, S.-J., \& Guan, Y.-G. (2013). Simultaneous Analysis of Ne-(Carboxymethyl) Lysine, Reducing Sugars, and Lysine During the Dairy Thermal Process. Journal Of Dairy Science, 96(9), 5487-5493.

Xu, X. B., Liu, D. B., Guo, X. M., Yu, S. J., \& Yu, P. (2014). Improvement of Sugar Analysis Sensitivity Using Anion-Exchange Chromatography-Electrospray Ionization Mass Spectrometry with Sheath Liquid Interface. Journal Of Chromatography A, 1366, 65-72.

Xu, X. B., Liu, D. B., Yu, S. J., Yu, P., \& Zhao, Z. G. (2015). Separation and Determination of 4-Methylimidazole, 2-Methylimidazole and 5-Hydroxymethylfurfural in Beverages by Amino Trap Column Coupled with Pulsed Amperometric Detection. Food Chemistry, 169, 224-229. 
435

436

437
Yaylayan, V. A., \& Keyhani, A. (2000). Origin of Carbohydrate Degradation

Products in L-Alanine/D- $\left[{ }^{13} \mathrm{c}\right]$ Glucose Model Systems. In Journal of Agricultural And Food Chemistry, vol. 48 (pp. 2415-2419). 
Figure Legends:

439 Figure 1 HPLC chromatograms of dicarbonyl derivatives obtained from the 440 glucose-ammonium solution with or without sulfite.

441 Figure 2 changes of the dicarbonyls as the function of heating time. A, B, C, D, E and

$442 \mathrm{~F}$ were the levels of 3-deoxyglucoseone (3-DG), methylglyoxal (MGO),

443 hydroxypyruvaldehyde (HPA), pentosone, glucosone and threosone as the function of 444 heating time, respectively.

445 Figure 3 Levels of 4-MeI as the function of sulfite concentration.

446 Figure 4 Proposed chemical mechanism of enediol transition affected by sulfite. 


\begin{tabular}{|c|c|c|c|c|}
\hline \multirow{2}{*}{ hexose } & \multirow{2}{*}{ sulfite ( $\mathrm{mmol} / \mathrm{L}$ ) } & \multicolumn{3}{|c|}{$\mathrm{H} / \mathrm{D}$ exchange ratio $(\mathrm{w} / \mathrm{w}, \%)$} \\
\hline & & $\mathrm{m} / \mathrm{z}=198$ & $\mathrm{~m} / \mathrm{z}=199$ & $\mathrm{~m} / \mathrm{z}=200$ \\
\hline \multirow[b]{2}{*}{ glucose } & 0 & 21.4 & 13.0 & 4.1 \\
\hline & 20 & 3.2 & 25.4 & 13.2 \\
\hline \multirow[b]{2}{*}{ mannose } & 0 & Nd. & 8.9 & 2.3 \\
\hline & 20 & Nd. & 18.9 & 7.8 \\
\hline \multirow[t]{2}{*}{ fructose } & 20 & 1.2 & 9.5 & 20.7 \\
\hline & 40 & $\mathrm{Nd}$. & 4.8 & 12.8 \\
\hline
\end{tabular}

448 Nd. is not detected. 


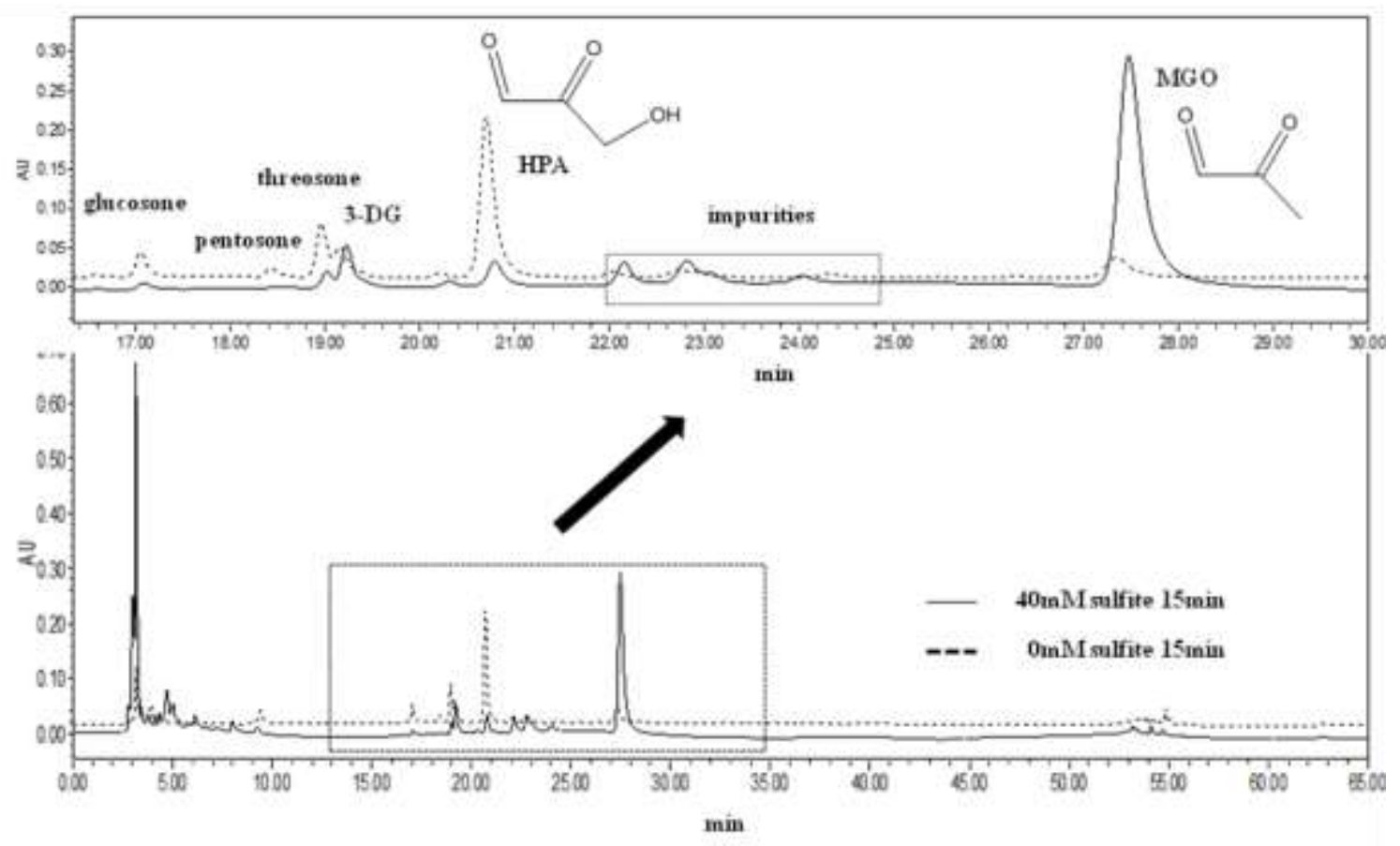

Figure 1 

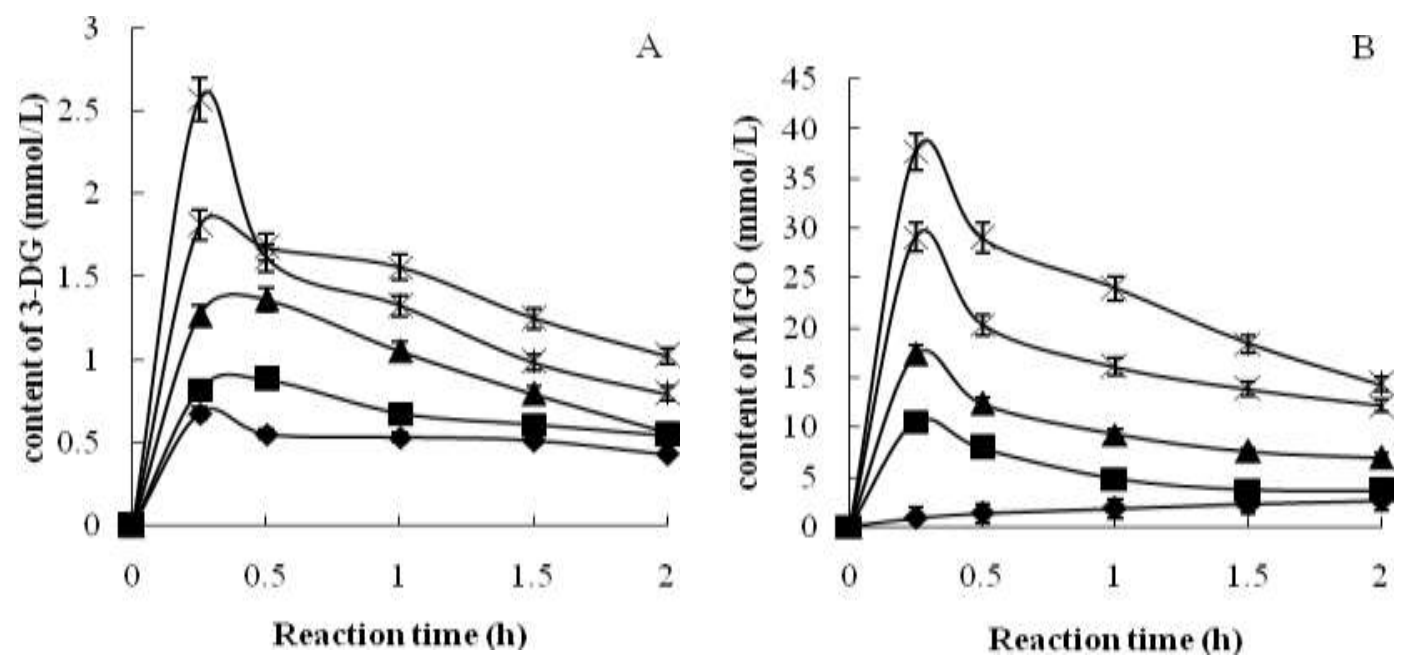

C
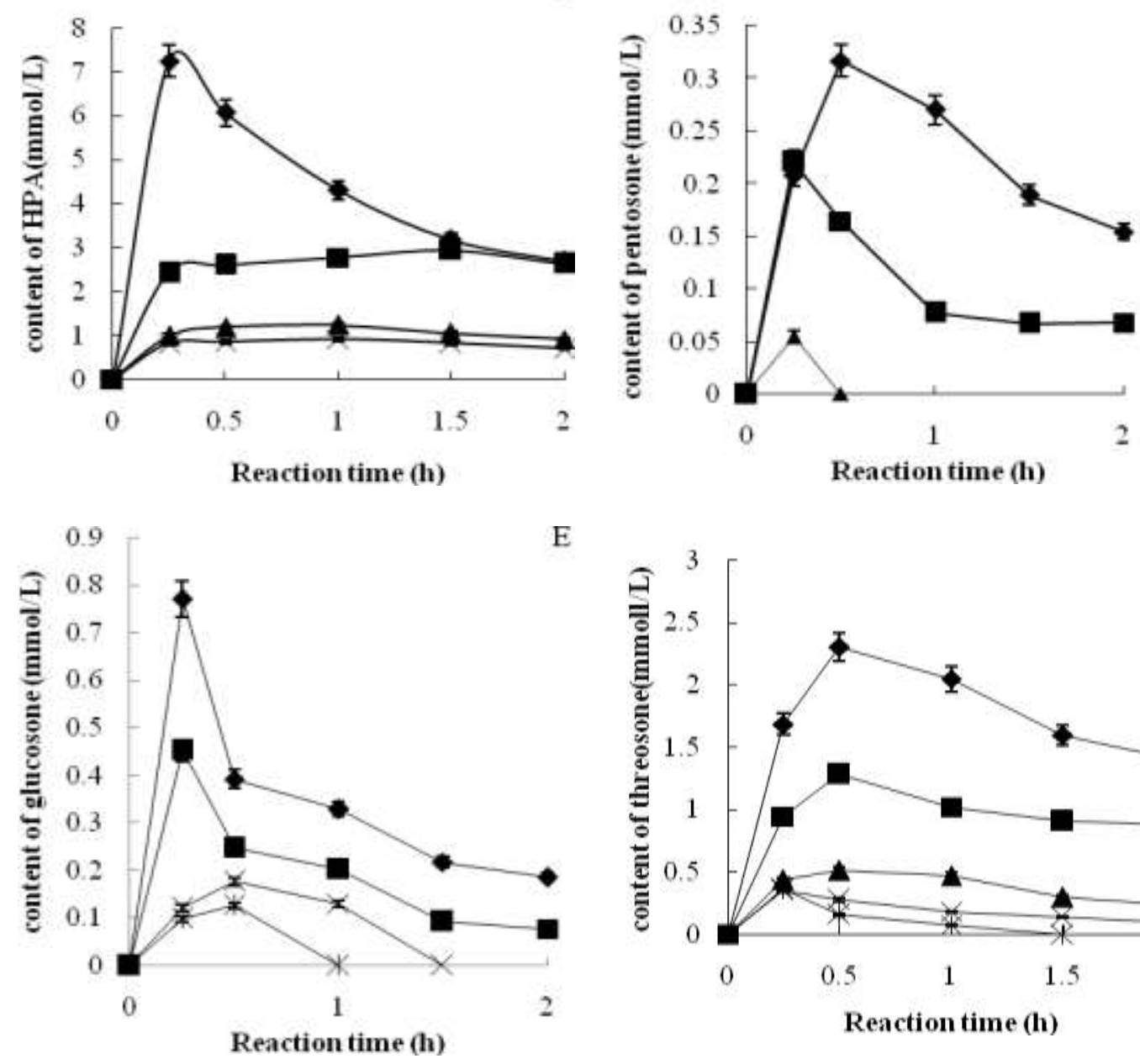

E

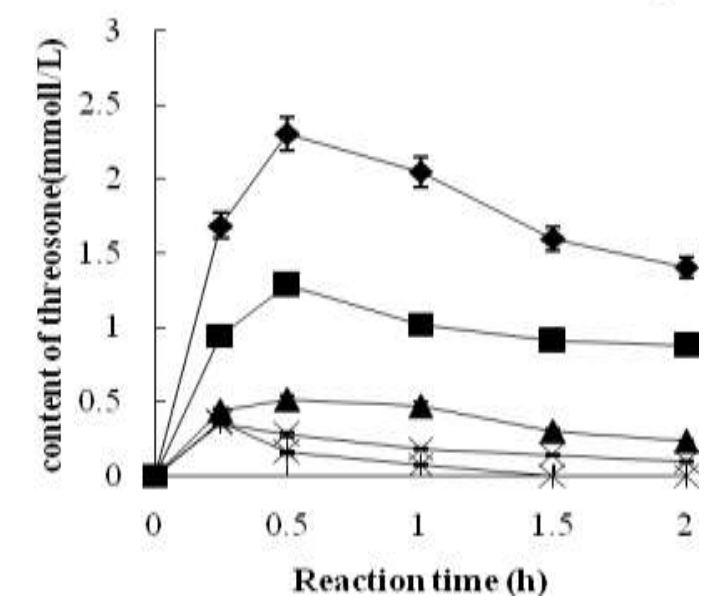

$\multimap 0 \mathrm{mmol} / \mathrm{L}$ sulfite

$-20 \mathrm{mmol} / \mathrm{L}$ sulfite

$\multimap-40 \mathrm{mmol} / \mathrm{L}$ sulfite

$\leftarrow 100 \mathrm{mmol} / \mathrm{L}$ sulfite

* $400 \mathrm{mmol} / \mathrm{L}$ sulfite

Figure 2 


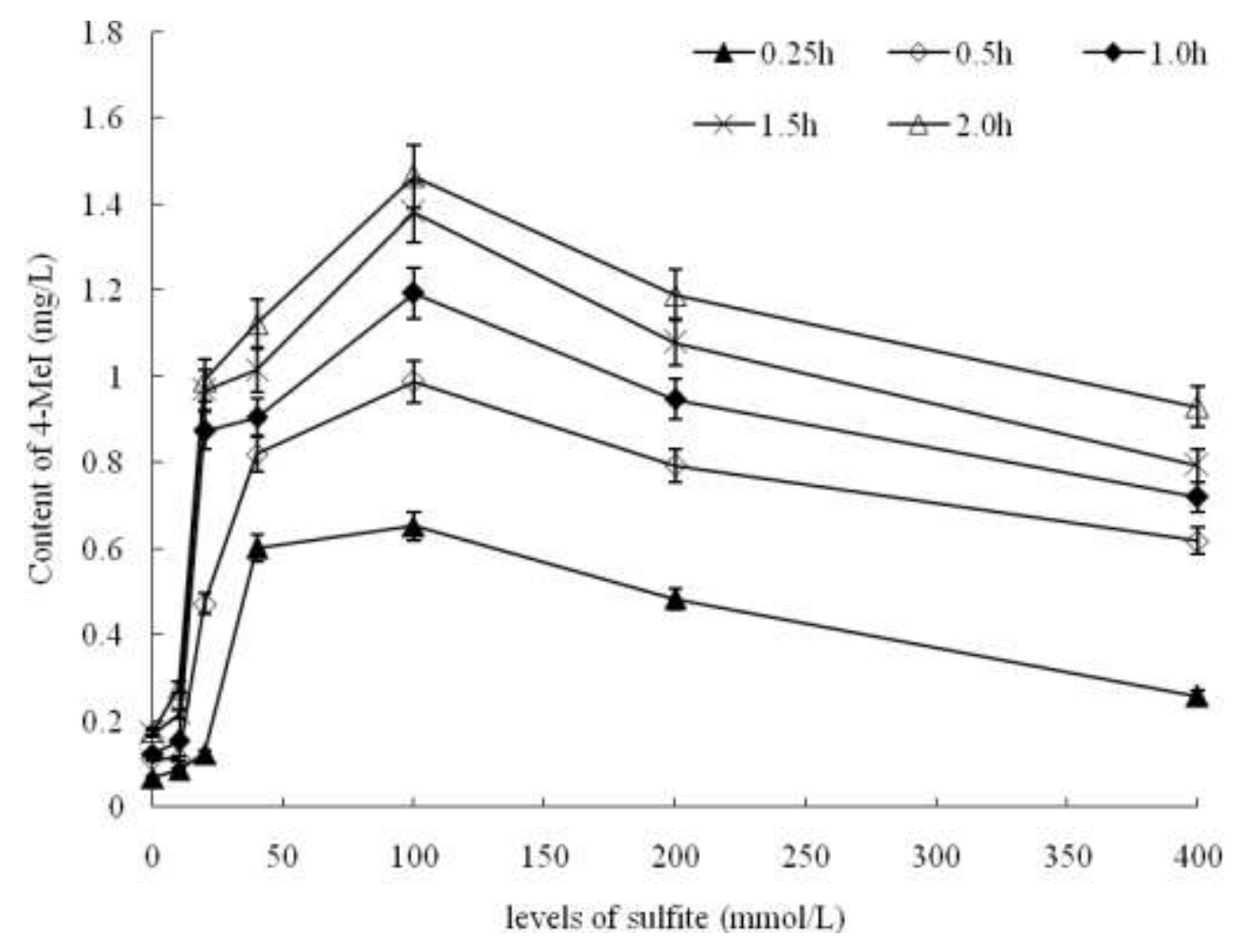

Figure 3 


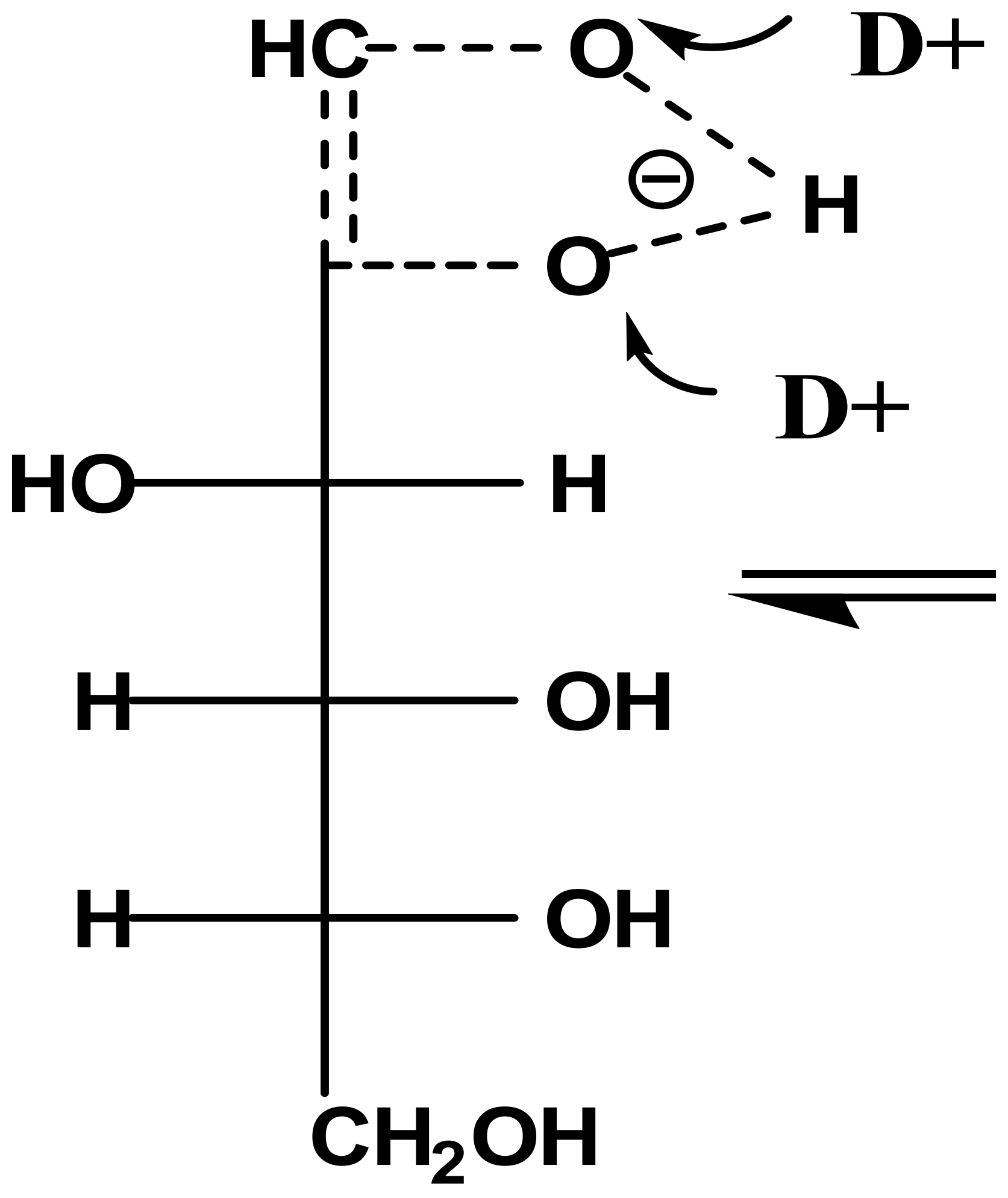

Figure 4

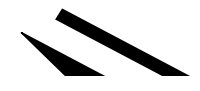

